\title{
The Jesuit College Ballets: What We Know and What's Next
}

\author{
Judith Rock \\ Independent scholar \\ wingrock@att.net
}

\begin{abstract}
The existence and nature of the seventeenth- and eighteenth-century ballets produced at Jesuit colleges in Catholic Europe, most often in France and German-speaking lands, is better known now, in the United States and in France, than it was several decades ago. Researchers have come to understand much more about the ballets, their motivation and widespread production, and their professionalism. The Jesuit college ballets are a rich nexus of art, theology, philosophy, and culture. Looking again at what we already know reveals questions that need to be addressed in future research. The most fruitful future research is likely to come from scholars committed to interdisciplinary work, including some physical understanding of dance as an art form. As with any phenomenon involving the meeting of an art form and theology, historians of the art form and historians of the theology tend to know and be interested in very different things. And their colleagues, historians of culture, may be interested in yet something else. As scholars approach a variety of possible future Jesuit college ballet projects, this interdisciplinary challenge can illumine more completely the commitments and intentions of the ballets' Jesuit producers, as well as the ballets' influence on their surrounding cultures, and the cultures' shaping of the ballets.
\end{abstract}

\section{Keywords}

Jesuit college ballets - baroque dance - kinesthetic identification - horse ballets ballet-tragedy connection - comedy - professional baroque dancers - verbal rhetoric - physical rhetoric - restaging 


\section{Introduction}

Someone, says Annie Dillard in The Writing Life, wrote that "each student of the ferns will have his own list of plants that for some reason or another stir his emotions." Part of the delight of researching anything is that in the process we are startled and enlightened and entertained by the surprising and singular passions of other scholars. Those passions keep our own burning. For nearly forty years, my emotions have been stirred and my mind fascinated, as both dancer and scholar, by the seventeenth- and eighteenth-century Jesuit college ballets. This is partly because they are a perfect example of the meeting of a sophisticated performing art and theology. Working on that shadowy boundary where art and theology meet has been my vocation as dancer, actress, novelist, and scholar. In this essay, I want to consider first what we know now about the Jesuit college ballets, and then what that younger scholar, who finds his or her emotions, mind, and imagination stirred by the ballets, might discover next.

What do we know now about the ballets? They were created and performed primarily in the French, German, and eastern European Jesuit colleges, from the middle of the seventeenth century until the early 1760 os and the suppression. In my own research, I have focused on the French college ballets, and especially on those created and performed in Paris at the college of Louis le Grand, the flagship of ballet production. Louis le Grand, originally called Clermont, was the only Jesuit college in Paris, though not the only college producing theater-many schools did so, having inherited the medieval tradition of student performance. By 1560 , Jesuits were teaching on the Left Bank at the college of Clermont on the rue de La Harpe, near the Seine. In 1563, Clermont moved to the nearby rue St. Jacques, where the Lycée Louis le Grand still stands. Clermont was renamed Louis le Grand in 1682 when Louis XIV (r.1643-1715) became its patron. There are numerous websites referring to "the Jesuit colleges" in Paris. This mistake probably arises from the 1690 Philidor collection of music, titled Ballets des jésuites, which for some unknown reason contains a score titled "Ballet d'Harcourt." The college of Harcourt, founded in 1280 , also produced tragedies and ballets. (It exists now as the Lycée St. Louis.) Though the Jesuit ballets seem to have been sometimes shared among Jesuit schools, there is no evidence that they were shared with non-Jesuit colleges.

1 Annie Dillard, The Writing Life (New York: Harper and Row, 1989), 67. 


\section{An Interdisciplinary Project}

The Jesuit college ballets are a rich nexus of seventeenth- and eighteenthcentury art, theology, philosophy, and culture, which means that working with their layered reality is always an interdisciplinary project. The researcher needs an understanding of pre-suppression Jesuit educational philosophy and Christian humanist theology, a working knowledge of the seventeenth- and eighteenth-century cultures that surrounded the colleges, and some physical understanding of dance - what it is and is not, and that it communicates from body to body, not verbal mind to verbal mind. This kind of communication is called kinesthetic identification.

In the ballets' own time, there was much speculation about the physicality of dance. The Jesuit dance historian and creator of grand events ClaudeFrançois Menestrier (1631-1705) believed that dance began with sound hitting the eardrum. He explained in his 1682 Des Ballets anciens et modernes ${ }^{2}$ that sound-especially the sound of violins—sent a ball-like thing called les esprits bouncing through the body and creating movement-like a small stone cast into water causes ripples. In our own time we would describe dance's physical communication as kinesthetic identification by the watcher with the dancer's movement, because of which and after which verbal reflection and response arises. Though baroque dance, as we now call the seventeenth- and eighteenth-century dance technique used on the Jesuit stage, had deep connections to verbal rhetoric, it was understood as physical rhetoric.

How does the non-dancer academic acquire more than an intellectual understanding of dance? By taking a few beginning dance classes, baroque if possible, but experiencing any precise and demanding technique will be useful. By going to dance concerts-baroque if possible, but professional modern dance or ballet will also be helpful — and noticing the physical response of one's body during the performance. And by watching the excellent videos on the New York Baroque Dance Company website — click on the Gallery tab - where there are examples of the two baroque technical styles, serious and comic.

Without this sort of effort, our perhaps limited contemporary understanding of dance will mislead us in understanding the college ballets. For example, some researchers have assumed that the ballets were like modern well meant but clumsy children's dance recitals. One researcher, not understanding the

2 Claude-François Menestrier, Des Ballets anciens et modernes selon les règles du théâtre (Paris: René Guignard, 1682). 
basic reasons for the ballets' production, concludes that they were a Jesuit ploy for pleasing parents. We always need to guard against what medievalist Caroline Walker Bynum has called "presentist" assumptions.

\section{The Dance Technique and Style of the Ballets}

Baroque dance technique itself tells us a great deal about the culture surrounding the ballets. To our eyes, the noble or serious style of technique, used for serious and important characters, is small and contained. Legs are never raised beyond a forty-five degree angle from the hip, arms never reach above the shoulder. The jumps and turns are precise and intricate, but because they stay within baroque dance's small frame, we may miss just how complex and difficult they are. We are accustomed to leotards, tights, and light flowing fabrics that show the body, especially the center body, and its movement. Baroque dance costumes covered most of the body: voluminous skirts and sleeves to the elbow for women, heavy jackets and breeches to the knee for men. Both sexes wear corsets and heeled shoes. Masks were often worn and elaborate headdresses were usual. Baroque dance technique's celebration of limits, precision, and small intricate complexity, of the luxurious weight of costume as part of movement, tells us much about the manners, ways of speaking and moving, and even thinking, in upper bourgeois and noble society during the century of the Jesuit college ballets.

Women were dancing professionally in France by the 168os, but on the Jesuit stage, male dancers performed the female roles-in spite of the Society's prohibition against theatrical cross-dressing. In court ballets, costume signaled that a "woman" was really a man or boy. For "noble" or serious characters, the skirt came only a little below the knee, garlands of flowers circled the calves, and a piece of fabric was tucked into the low cut bodice and gathered around the neck. For adult male dancers, these alterations helped hide bulging male muscles and chest hair. Most of the boys of the Jesuit stage would not have needed these precautions, and the costume may have served as a reassurance to the audience that no women were performing.

Both male and female comic characters in seventeenth- and eighteenthcentury ballets danced in what became known as the Grotesque style of dance, which was in sharp physical contrast to the noble or serious style. In 1716, Gregorio Lambranzi , a Venetian ballet master and performer active in the late seventeenth and early eighteenth centuries, published his book The New and Curious Style of Theatrical Dancing, about comic ballet characters 
and their dances. ${ }^{3}$ In dance, "Grotesque" described a contrast to noble beauty, self-possession, and restraint. The contrast of the Grotesque ballet character to the noble characters, and the function of the Grotesque characters, is very much like the relation of nobles and peasants in the plays of Shakespeare (1564-1616) and Molière (1622-73). The Grotesque style pointed a social norm and carried a social judgement, in that its characters were invariably peasants, fools, drunks, impossible dancing figures like pumpkins and onions, arguing couples, and others behaving outside upper class or noble norms. Grotesque figures also presented comic optical/kinetic illusions, such as a dancer appearing to carry someone on his back in a basket, or a pair of dancers, each appearing as a single leg. Grotesque movement was big, sloppy, and heavy, legs were wide apart and turned parallel or inwards rather than outwards as in the noble style, arms were flung, bodies bent and crouched, with obvious physical comedy results. On the New York Baroque Dance Company website, in the Gallery section, there are several excellent short videos of dances reconstructed from Lambranzi's book which show the comic/Grotesque dance style. In the Jesuit college ballets, characters dancing in that style were often those acting outside the moral and Christian virtues the Jesuits hoped to instill in their students.

\section{Why the Ballets Were Produced}

When I mention the college ballets in non-specialist conversation, the first question-after "Jesuit what?!" - is usually, “Why?" The most important reason for the ballets' production was that the teaching of rhetoric - the art of communication - was central in the Jesuit college syllabus, laid out in the Ratio studiorum of 1599. The early connection of rhetoric with theater is cautiously mentioned in section eighty-seven of the 1599 Ratio. That section says that theatrical tragedies and comedies should be "only in Latin and extremely rare, should be holy and devotional [...] nor should any female character or clothing be introduced." Very soon all of these stipulations except for the Latin requirement were being progressively ignored by many colleges, the contentious record of which is preserved in the archives of college correspondence with Rome.

3 Gregorio Lambranzi, New and Curious School of Theatrical Dancing (Nuremberg: Johann Jacob Wolrab, 1716).

4 The Ratio studiorum: The Official Plan for Jesuit Education, trans. and ed. Claude Pavur, S.J. (St. Louis, MO: Institute of Jesuit Sources, 2005), 35. 
The verbal rhetorical training of speaking and acting in the tragedies included the physical rhetoric of stance, movement on the stage, and gesture. The proper use of gesture, of arms, hands and fingers, was part of teaching both verbal and physical rhetoric. The Jesuits' students learned the precise gestural vocabulary shared by seventeenth- and eighteenth-century actors, dancers, preachers, lawyers, and singers - and by important men having their portraits painted. In some portraits of Louis XIV, he stands in baroque dance's fourth position, and holds his arms and hands in much the way a baroque dancer would. There were many educational gesture manuals in use in the seventeenth and eighteenth centuries, and probably also in Jesuit colleges, which showed the rhetorical gestures of the hands and fingers and taught where and when they should be used.

Because the ballets at Louis le Grand and the other French colleges trained students in French culture's most important physical rhetoric, they quickly joined the tragedies as part of the annual late-summer prize-giving. The first recorded ballet at the Paris college was done in 1638 , not at prize-giving but most likely in October, to celebrate the birth of Louis XIV. ${ }^{5}$ Beginning in 1650 , ballets were produced at the college almost every year until 1762, to accompany the tragedies performed at prize-giving. ${ }^{6}$

Not all Jesuit colleges were as prolific of ballets as was Louis le Grand, though most, if not all, French colleges, and also German colleges, produced them. As I have said, ballets were apparently shared among colleges, probably both livrets and dances. They were also sometimes repeated within a college. There was a ballet called Orphée at the College of La Fléche in 1689, and an Orphée at Louis le Grand in 1690; ${ }^{7}$ Avignon produced Le Jeux Olympiques in 1707 , and there was a ballet of the same name at the College of the Trinity in Lyon in 1714. ${ }^{8}$ At Louis le Grand, there was a France victorieuse sous Louis le Grand (France Victorious under Louis the Great) in 1680 and also in $1687 .{ }^{9}$

The French cultural reason for this training in physical rhetoric was that in the adult lives of upper class students, physical self-presentation and mastery in dancing would be crucial for achieving a place in society, maintaining reputation, and forming social relationships. The test for taking one's place

5 Robert W. Lowe, Marc-Antoine Charpentier et l'opéra de collège (Paris: Maisonneuve et LaRose, 1966), 176.

6 Ibid., 176n95.

7 Ibid., 181 .

8 Website Exposition Archives Municipal de Lyon: Lyon et l'Olympisme, 15 mai-3 août 2013, Les Jeux Olympiques à Lyon 1714, 6 .

9 Lowe, Marc-Antoine Charpentier, 179-80. 
at Louis XIV's court was to dance with a partner before the king, with all the courtiers watching. There is a story of one young man who had not practiced enough, fell on his face, and was sent abroad by his father until the considerable scandal died down and he could try again. There is also a story of a boy from a highly placed legal family who was expected to go into the army. His dancing master had to inform the boy's father that the boy was simply incapable of learning to dance. Which meant that he could not be an army officer, because he would be excluded from the balls and social occasions at which most of the important necessary communication took place among the officers.

Other forms of culturally shaped physical rhetoric were also presented where dance was less important. In German-speaking lands, where horsemanship seems to have been an important way of communicating mastery, order, and precise physical skill on the part of both horse and rider, some Jesuit colleges staged horse ballets, complex equestrian events which were probably something like the contemporary feats of the Austrian horses called Lipizzaners. When looking up the spelling of Lipizzaner, I discovered a video of an annual Christmas event held near Johannesburg, South Africa, called "Lipizzaners and Carols by Candlelight," also known as "The Ballet of the White Stallion." The video excerpt shows the South African Lipizzaners and riders performing with orchestra and choir. The spectators have little candles in paper holders, as on Christmas Eve in churches. Some of South Africa's European cultural heritage is German, and I suspect that the "Ballet of the White Stallion," in the decorated indoor performing hall, is much like the seventeenth- and eighteenthcentury German horseback productions. If you are wondering what a Jesuit college horse ballet might have looked like, I recommend watching this video (https://www.youtube.com/watch?v = FMwSXgGXrZg).

Italian and Spanish colleges apparently did not produce ballets (human or horse), though they staged elaborate musical productions and religious tableaus. The Portuguese colleges produced plays and apparently had a particular interest in music. Baroque music, too, had connections with rhetoric. According to baroque opera specialist Olga Termini, "In Italian baroque opera [...] the concerns of the camerata and the emergence of the stile recitativo attest primarily to the goal of moving the affections through the words."10 The national and local culture surrounding each college explains the emphasis on different theatrical forms, but all the forms, even music, were understood as rhetoric, communication intended to move, persuade, and please the audience.

10 Olga Termini, "The Role of Diction and Gesture in Italian Baroque Opera," Performance Practice Review 6, no. 2 (1993): 146-56, here 146. 
The plays, ballets, horse ballets, and musical performances-many of which included dance - were much loved by audiences. Jesuit Charles Porée (1676-1741) left this poem, found among his papers after his death.
Musicians, dancers,
It was only they the audience loved;
for them the audience hardly had eyes and ears enough.
But during the piece [tragedy]
they emptied their bottles;
their shouts and applause
were only for the leaping. ${ }^{11}$

Of course, the Jesuits' religious and political adversaries, like the quasi-Calvinist Catholic Jansenists and the University of Paris, threw verbal rhetorical bottles at the whole theatrical enterprise. But the Jesuit theater remained very popular with audiences, both lay and religious, and with influential personages on whose continuing good opinion the Jesuit enterprise depended for its existence in every town and realm.

The Jesuit concern for pleasing and praising those in charge in the surrounding world has led at least one historian to categorize the Jesuit college theater as simply an influential part of promoting monarchical absolutism. ${ }^{12}$ The French Jesuits certainly sought to please, and also to influence the actions of those who had power over their future, going so far as to re-name the Paris college after Louis XIV when he became patron of the prize-giving there- - that is, he paid for the prizes. Though often distasteful and unacceptable to modern eyes, the efforts to please and influence the king were on a continuum with Louis's Jesuit confessor's efforts to influence his actions religiously and politically. Again, we have to be aware-and beware-of our "Presentist" allegiances, if we are to put these efforts in an accurate historical perspective.

The Jesuits always understood their theater as "a school of virtue," as the Jesuit Porée described it in his March 13, 1733 oration at Louis le Grand, "Whether the Theatre is or can be made a School for forming the Mind to Virtue."13 The plays and ballets were understood as part of the Jesuit theological and moral mission to king, court, nobility, and the upper classes in general, the people

\footnotetext{
11 Pierre Peyronnet, "Le théâtre des jésuites," Dix-huitième siecle 8 (1976): 107-20, here 117.

12 Sara Beam, Laughing Matters: Farce and the Making of Absolutism in France (Ithaca: Cornell University Press, 2007), 210-40.

13 Charles Porée, Whether the Theatre Is or Can Be Made a School for Forming the Mind to Virtue, trans. J. Lockman (London: T. Astley, St. Paul's Churchyard, 1734).
} 
making and influencing what we would call policy decisions at every level. Just as the Society of Jesus routinely used elements of foreign cultures to help them communicate in their missions, they used the production of plays and ballets to communicate with, influence and convert-or reconvert-European princes, nobles, and upper class people in cities and towns. The Jesuit Constitutions of the period put their concern and intent in these words: "It is helpful in general to strive to retain the goodwill and charity of all [...] and especially of those whose favorable or unfavorable attitude toward [the Society of Jesus] is of great important for opening or closing the gate leading to the service of God and the good of Souls." ${ }^{14}$

None of this means that the Jesuit educators ignored ordinary people. They recognized that the cultural language of ordinary people was not the language of ballet and tragedy, and addressed them and their needs in different ways. One way was by providing free education for day students: sons of the poor, of ordinary workers, and of craftsmen and small merchants. Molière, whose father was an upholsterer, was a Louis le Grand day student. So far as is known, day students did not perform in the annual tragedies or ballets.

Beyond teaching students and preparing them for the future, or pleasing and teaching audiences or princes, the deepest reason for the Jesuits' attention to physical rhetoric was that they were Christian humanists who believed the physical creation, including the body, to be essentially good in and of itself; and they believed in the incarnation of Christ: God come to humanity in human flesh. Nonetheless, the 1599 Ratio's decree that performances were to be devotional was not followed. In the next century, Menestrier cautioned librettists not to mix what belonged to the altar and what belonged to the stage. For example, ballets occasionally included Religion as a character and religion as a concern, but neither was presented in a devotional way.

\section{The Ballets in Performance}

The five Act tragedies, originally in Latin, later sometimes in the vernacular, and the four Part ballets were only tangentially related. Louis le Grand's 1699 summer tragedy was Joseph établi vice-roy d'Egypte and the ballet was Les Songes (Dreams). ${ }^{15}$ But nothing in the ballet referred to Joseph's dreams. The ballet was about ordinary dreams, ideas about dreams, etc. The ballets had four Parts,

\footnotetext{
14 The Constitutions of the Society of Jesus, ed. John Padberg, S.J. (St. Louis, MO: Institute of Jesuit Sources, 1996), 406.

15 Lowe, Marc-Antoine Charpentier, 183.
} 
and ended with a Ballet General. The tragedy began with a prologue, spoken by a student and followed by the play's first Act. Then the ballet's first Part was danced, followed by Act II of the tragedy, followed by Part II of the ballet, etc. After the tragedy's fifth Act, the Ballet General was danced, bringing all the dancers, student and professional onstage, and leading by some dramatic device into the prize-giving.

The prize-giving performance took place on an outdoor stage constructed in the college courtyard. There may be a relationship between a college's possession of a large courtyard and the beginning of ballet production, which usually included the most elaborate staging, machinery, and effects possible. The tragedy and ballet performances and the prize-giving drew large audiences, which included upper class citizens, religious of other orders, parents and families, and sometimes nobility and royalty. The large courtyards, surrounded by college buildings of several stories, provided space for seating: men in the courtyard on benches and women on chairs at the buildings' many windows.

Louis le Grand's main courtyard appears on architectural drawings of the college by $1628 .^{16}$ As we have seen, the college's first recorded ballet was produced ten years later. Jesuit colleges also needed indoor performing space where smaller audiences could be accommodated. They often produced plays during the winter and early spring, and also organized frequent rhetorical displays. Judging from a plan of Louis le Grand dated 1762, one of the uses of the long classroom at the east end of its court was as a theater. On that plan, the long room is designated as "Theatre," "Logique," and "Musique." A neighboring and seemingly only partially separate space to the south is labeled "Cinquième," and may have been usable as part of the theater. ${ }^{17}$ Other French colleges known to have had indoor theaters include those at Bordeaux, Dijon, La Flèche, Pont-à-Mousson, Rouen, and Reims. Rouen's indoor theater could hold about a hundred spectators. ${ }^{18}$ The outdoor courtyard performances accommodated many more: Louis le Grand's courtyard, and surrounding windows were often said to seat more than a thousand. Judging from today's Louis le Grand courtyard, this seems impossible, but the buildings, courtyards and other open spaces have undergone many changes over the years, and not all of them seem to have left surviving records.

At Louis le Grand, the west-facing stage, with its understage area, trap doors, and overhead flies, was constructed at the east end of the great courtyard,

16 Clémentine Mathurin, "Du collège de Clermont au collège Louis le Grand: Architecture et histoire d'un collège jésuite à Paris 1563-1792" (MA thesis, Sorbonne: 2009-10), 2:15.

17 Ibid., 2:35.

18 Beam, Laughing Matters, 235. 
backing up against the tall windows of the rhetoric classroom. Wooden steps were built, and the classroom served as the backstage, with the windows as stage access. The college is on the east side of the rue St. Jacques, and the ballets were performed in the afternoon, so the mid-afternoon sun would have been behind the east facing spectators. Though an enormous canvas was stretched over the courtyard in case of rain, the afternoon daylight would have contributed to the stage lighting. Other lighting was from candles in sconces nailed to the stage ends of wings, and perhaps in a large wheel of candles suspended from the flies.

Scenery included painted backdrops and wing flats, and many stage effects were used. Denizens of the underworld came and went through trapdoors, gods and goddesses descended from the sky on painted clouds lowered from the flies, seas were wide, blue satin ribbons stretched from wing to wing across the stage and manipulated by stagehands so that the water seemed to ripple and shine. Stage machines, like the huge hydra used in the 1686 ballet The Labors of Hercules, ${ }^{19}$ moved along small rails laid on the stage, guided by students hidden inside, who also made the hydra's mouth emit clouds of smoke. Musicians sometimes emerged from elaborate machines or were placed precariously in the branches of scenery trees. Snowstorms of sugar fell from the flies, lightning flashed, and thunder growled.

The ballet livrets were written by Jesuit rhetoric professors like Joseph Jouvancy (1643-1719), Gabriel Le Jay (1657-1734), and Porée. The student actors and dancers were boarding students from the upper rhetoric class. These boys were well to do and socially highly placed, and their families helped pay for the elaborate costumes necessary for the productions. Some boys were sons of the old nobility of the sword, a few were royal, and many came from the new nobility of the robe-that is, legal professionals - and some, especially in provincial towns, were well-to-do upper bourgeois. They would have begun learning to dance at the age of seven or so, and by the time they arrived at Louis le Grand, usually somewhere between ten and fourteen years of age, most of them would have been reasonably competent dancers. So the decision to produce ballets meant using a skill most of the boarding students already had.

Professional dancing masters created, taught, and rehearsed the dances in the ballets. Even small provincial towns would have had at least one dancing master. Though many Jesuit professors would have danced in their youth, it was understood that no Jesuit danced, even in order to teach. Because Louis le Grand was in Paris, the known ballet masters who worked at the college from

19 Les Travaux d'Hercule, Bibliothèque nationale de France, Paris, Rés. Yf 2855. 
the later seventeenth century through 1761 included the most accomplished and famous in Europe. The best known is Pierre Beauchamps (1631-c.1719), dance director of the Royal Academy of Music and credited by dance historians with inventing the five positions still used by all Western concert dancers. He also invented the comprehensive system of dance notation, which has the dance's music across the top of each page, and through which baroque dances have came down to us. It is called Feuillet notation, after Raoul-Auger Feuillet (c.1660-1710) fellow dancing master and colleague, who published it. Louis Guillaume Pécour (1653-1729), and Michel Blondy (1677-1747) also choreographed and directed Louis le Grand ballets, as did eighteenth-century masters Froment, Laval, and François-Antoine Malter (167?-1761). Being a professional ballet master meant being also a musician, playing the small violin necessary for teaching and rehearsing dances, and composing music for the dances and other parts of the ballets.

The best male professional dancers from the Royal Academy (which became the Paris Opera) often danced alongside the Louis le Grand students. Professional dancers named in Louis le Grand ballet programs include Blondy, Claude Ballon (1676-1739), Antoine Germain, Louis Bouteville, Feuillet, Dominique Magny and his son Claude-Marc (b. c.1677), Gaetan Vestris (1729-1808), known as "the god of the dance," and many others. ${ }^{20}$ It would be interesting to know if the Feuillet named as part of the professional cast of the 1690 ballet Orphée ${ }^{21}$ is the Raoul-Auger Feuillet who published Pierre Beauchamps's system of notation. The date is right for his career as dancer and ballet master, and he is known to have worked with Pécour, who was ballet master for the production. But only student performers' full names were listed, at the end of the program. Only the surnames of professional dancers appeared, and in the body of the program, at the points at which they danced. Little is known of Raoul-Auger Feuillet's life beyond his work with notation, though the noted French researcher Régine Astier is currently working with period notarial documents in the hope of discovering more about him.

Though there is no concrete evidence, it seems likely that Beauchamps taught his notation system to at least some of his Louis le Grand students, or perhaps left notated records of his dances to be kept in the college library for reuse. Unfortunately, much of the college library was scattered or lost when the University of Paris took over the property after the Jesuits' expulsion. If

20 The birth and death dates of many well-known seventeenth- and eighteenth-century dancers are not known.

21 Orphée, Bibliothèque nationale de France, Paris, Res. Yf 2765 . 
there were notation manuscripts, they were probably sold to the markets for wrapping paper.

We have little visual record of the Jesuit ballet stage, and it is often difficult to know if the few Louis le Grand stage decor drawings that exist are for the ballet or the tragedy. In the program of the tragedy Adonias, presented at Louis le Grand in 1648, there is a drawing of student actors-six male and two female characters-performing Act IV of the tragedy Adonias, before a backdrop showing classical pillars and a terrace. ${ }^{22}$ So far as I know, there are no drawings of dancers, either student or professional, onstage in a Jesuit college production. There are, however, some drawings of professionals who are known to have danced at Louis le Grand, including the drawing of Magny, who performed several roles in the ballet Orphée in 169o. In the drawing which accompanies this article, he is masked and costumed as an old man in a secular ballet.

\section{The Ballets and Rhetoric}

I have said that the ballets were intended as training in physical rhetoric. Like the tragedy livrets, the ballet livrets often began with an "Argument" in the rhetorical sense. In verbal rhetoric, the argument is the statement of the rhetorician's intent and procedure. In the 1687 Louis le Grand ballet, La France Victorieuse sous Louis le Grand, the "Argument" printed at the beginning of the program reads:

It is not only by the force of arms that France is victorious under Louis the Great: she is even more victorious by the laws that this prince has so wisely established; by the arts, which he has made flourish again with such brilliance; but above all by peace, which he has generously given to Europe. France triumphs by law over the principal disorders that injustice has introduced; over ignorance by the arts; over her enemies by arms; and over herself, in the end, by peace. These four kinds of triumph which are uniquely the work of Louis the Great, and which make France under his reign the most illustrious of all the nations, will be the subject of the four Parts of the ballet [translation mine]. ${ }^{23}$

\footnotetext{
22 Regi christianissimo agonothetae munificentissimo Adonias, Bibliothèque nationale de France, Paris, Rés. YF 2614.

23 La France Victorieuse sous Louis le Grand, Bibliothèque nationale de France, Paris,, Res. YF 440.
} 
Each of the ballet's four Parts presents one kind of triumph, so it is reasonable to assume that the college ballet creators thought of the ballets' standard four Parts as at least similar to Aristotle's four parts of a verbal rhetorician's speech.

Greek and Roman speeches are traditionally divided into four parts: prooimion, diegesis, pistis, and epilogos, that is, introduction, narrative, proof, and epilogue. Rhetoricians proposed many subdivisions, and the parts were at times given different names. But the four-part speech and the parts' individual functions were familiar throughout the rhetorical tradition: the prooimion should inform the audience of the matter at hand, seize its attention, and win its goodwill. The narrative should give a clear and persuasive account of the speaker's version of events. The proof should confirm the narrative. The epilogos should recapitulate the argument and make a final emotional appeal to the audience. ${ }^{24}$

Each Part of the ballet was made up of a variable number of entrees, and the entrees were made up of dances, dramatic action, music, and often songs, sometimes sung by a dancer as he danced. Not only were the four Parts of the ballet at least somewhat like the four parts of a speech, each separate dance within the ballet could be understood in rhetorical terms. Dances were usually notated in four pages, and it is in the notation that the connection of dance and rhetoric is clearest.

Each notated page was understood (though no doubt more by ballet masters and rhetoricians than by the average dancer) as a section of a "speech." This physical rhetorical presentation is meant to persuade the audience of the expertise and efficacy of the character being presented. At the top of the page are the musical measures which accompany that page's movement. The large pattern of lines on the page shows the floor path of the dancer, where he or she goes in space. This floor path is called the "figure" and is related to the verbal rhetorician's "figure of speech." A small half circle with a double outline, if the dance was created for a woman-tells us where the dancer begins the path. The complicated smaller marks along the floor path line are her steps. On the first page of an early eighteenth-century gigue, she dances downstage, ingratiating herself (or her character) with her audience, as in the first part of a verbal rhetorical speech. She presents herself to the audience and literally shows her various sides, in preparation for persuading and moving the watchers.

24 Michael de Brauw, "The Parts of the Speech," in A Companion to Greek Rhetoric, ed. Ian Worthington (Wiley-Blackwell, 2007), 187-202, here 187. 
On the second page, she states her "case," clearly, concisely, and in a balanced manner: she dances in a sweeping circle to her left, withdraws upstage, approaches the audience again to make a contrasting sharp-angled pattern in order to show "the other side," then once more withdraws upstage.

On the third page, she tries to "prove" her "case," dancing in the most complex floor pattern, or figure, of the dance. This figure is full of circling jumps and turns, and it ends at the heart of the matter-in the exact center of the stage.

On the fourth and final page, she dances downstage once more, making a last effort to "move" the audience. As on the second page, this figure is clear, brief, and balanced, each side of the "figure" being clearly differentiated. Finally, her physical rhetorical communication finished, she withdraws to stillness and the place from which she began.

I have presented this description of a single dance and its notation in such detail partly as an additional way of demonstrating why we cannot simply approach the college ballets with what we think we know about dance in our own time. Our assumptions have little relation to the thickly layered seventeenthand eighteenth-century reality. To repeat, the phenomenon of the ballets is a rich and complex nexus of baroque art, Jesuit theology and philosophy, and the now vanished culture of its time.

But seeing the richness that is there from our distance in culture and time can feel like trying to untie the Gordian knot. For American researchers, the problem is complicated by there being so little archival material held in this country. Of course, many French documents are available online from the Bibliothéque nationale de France, through Gallica. The trouble with digital documents, useful as they are, is that they communicate little or nothing of their time-ness, to coin a word. When I hold in my hand a seventeenth- or eighteenth-century ballet program or copy of the Mercure monthly "newspaper," or a book or a piece of clothing from those centuries, something altogether different is happening. I am literally touching these centuries. Something of the time communicates itself physically to my fingers, and nose, and sense of rhythm as I read the period language or feel the texture and weight of fabric. It is my strong belief that researchers need this experience, no matter how much is available on a screen. History is not simply an idea or a piece of information. It is the pursuit of lost worlds, which have left behind small, tangible, physical pieces that tell us more than words.

In France, the Bibliothèque nationale, the Bibliothèque de l'Arsenal, and the Bibliothèque Mazarine in Paris, and the Bibliothèque municipal de Lyon hold extensive ballet archives from the Jesuit colleges, principally livrets and programs, but also a few stage drawings, as well as various seventeenth- and 
eighteenth-century Jesuit writings on dance and its value and purpose in the Jesuit theater. The small group of Jesuit ballet music scores which I have mentioned, the Philidor collection, is at the Bibliothèque nationale. The only titled score is Sigalion, whose music is by Pascal Colasse (1649-1709). Sigalion ou le secret ${ }^{25}$ was produced at Louis le Grand in 1689 , with dances by Pècour. It is the only Jesuit college ballet for which we have both the program and the music.

The fact of the college ballets is more widely known now than it was forty years ago. But even at the Lycée Louis le Grand, the century of ballets produced there are little remembered. This is partly because of France's long history of anticlericalism, but also because of the usual academic lack of attention to the arts, and especially to the very physical art of dance. In 2013, I took the Louis le Grand ballets back home. The senior English teacher at the school had read my four historical novels set at Louis le Grand in 1686 and 1687, whose central character is a Jesuit scholastic who teaches rhetoric and helps produce the ballets. Through her, I was invited to speak about the ballets and the novels at Louis le Grand's $45^{\text {th }}$ Anniversary Symposium. Reintroducing the Jesuit college ballets in the place where the most illustrious of them were created was an utterly unexpected and very great honor, and the crown of nearly forty years of work.

\section{And Now?}

What about the next forty years? What might be next in our efforts to understand and communicate the Jesuit college ballets?

In November 2005, Sigalion, the ballet whose score is in the Philidor collection, was restaged in Paris by historian Anne Piéjus, and baroque dance expert Christine Bayle. ${ }^{26}$ The performance was in an auditorium at the Bibliothéque nationale. As I have said, we have the program and music for this ballet, but not the dances. But the score gives the characters, and the music itself tells us the emotional and theatrical tone of the dances. Christine Bayle created new dances to go with the score's dance music in the score. But, very sadly, the production was not videotaped.

25 Sigalion ou le secret, Bibliothèque nationale de France, Paris, Res. YF 2834-35.

26 Plaire et instruire: Le spectacle dans les collèges de l'Ancien Régime, actes du colloque de Paris, dir. Anne Piéjus (Rennes: PUR, 2007): 287-30o. See also Carine Barbafieri and Laura Naudeix, "Polymestor à l'épreuve du secret: L'efficacité du regard," XVIIe siècle 238, no. 1 (2008): 27-39. The full issue is devoted to Sigalion. 
Restaging this ballet yet again, or reviving the very professional 2005 production, and filming it is one of the most important projects that could be done for the field of Jesuit college ballet research. This could be done by bringing the 2005 directors and dancers to an American Jesuit university. Students could be involved in appropriate ways, and the visiting baroque dancers might offer workshops or classes in the technique and style of the period. The directors might teach about the ballet as guests in a few history or French classes. This would certainly cost money, but if the project were tied to an important Jesuit celebration or to a university program, money might be raised.

Another way to do this would be to invite the directors of the French project to this country, to set the ballet on an American baroque dance company. Or an American company could use the Sigalion score and program to do their own restaging. Though creating a new restaging would take longer than remounting the ballet, and would probably be more expensive. But the potential value of a film record of Sigalion, with copies of that record put in appropriate libraries, would be incalculable to the fields of dance, music, and Jesuit history. We have many videos of seventeenth- and eighteenth-century dances recreated from Feuillet notation. But the dances are not the most important reason for restaging or recreating the college ballets. The ballets used the secular dance technique and dance forms, but differed in other ways from secular ballets. The world of French baroque dance assumed that a ballet might communicate political statements and comment on people and events. Though court and secular theater ballets were usually about the loves and pleasures of gods and mortals, the characters were very often allegories for king, consorts, and other important figures. The Jesuits treated female roles and characters differentlyin the tragedies, women were occasionally moral and political heroines, and in ballets, Religion was a female character. The major difference of intent and shaping between secular and Jesuit ballets is that the Jesuits used their ballets to speak morally, socially, and politically to contemporary society.

Whether or not the contemporary researcher agrees with the period moral, social, and political commitments of the Jesuit creators and producers, these differences are important historical reasons for restaging and recording selected ballets. The recordings would be held in the archives of the fields of dance, culture, and Jesuit theater. Many religious orders and their colleges of the seventeenth and eighteenth centuries produced plays, and some produced ballets. But the Jesuits' use of professional dancers-in spite of vociferous criticism - and high-level staging to present full-length ballets to knowledgeable audiences is a singular instance of a Christian religious order committing itself to the regular production — and costs — of (at least at Louis le Grand) state of the art dance as part of its communication and mission over the course of a 
century. This unprecedented and unrepeated meeting of dance and theology is in itself a compelling reason for the restaging and recording of the ballets.

So far as I know, Sigalion is, even now, one of only two Jesuit ballets which have been restaged. The other was L'Esperance, first done at Louis le Grand in 1709, which I restaged at the University of San Francisco in May 1986. That production, using student dancers and done on a very small budget, was commissioned by the late Dr. Lynn Farwell, S.J., to celebrate the Jesuit School of Theology at Berkeley's fiftieth anniversary. Like Sigalion, my L'Esperance was a restaging, not a reconstruction. So far as we know, no complete reconstruction of a Jesuit college ballet is possible, because we do not have all the pieceslivret, program, dances and music - for any single ballet. I chose dances, with their music, from the 1700 Feuillet collection of notated dances, and the music director chose appropriate baroque music for the prelude, songs, etc. That small production was videotaped, and the tape was part of my presentation at Louis le Grand in 2013.

Another research area which has been little explored is the place of comic characters and entrees in ballets produced at a variety of Jesuit colleges. This would mean looking at the surviving livrets and programs, culling the comic characters and scenes, and considering the differences in the colleges' settings: country and region, and whether provincial, capitol, or large or small provincial town. Because of the ballets' moral character, and their underlying religious character, their comic dimension has been little considered: some researchers mistakenly assume that their moral dimension and religious underpinnings mean that they have no comedy. The summing up of the Jesuit college theater productions - ballet as well as drama - as part of "the discourse of absolutism" I mentioned above, gives at least the impression that neither drama nor ballet was likely to include comedy, which both clearly did.

Looking first at comedy in the college dramatic pieces would be a useful preliminary to looking at comedy in the ballets, because it would create a theatrical context for how comedy was viewed and used across the Jesuit theatrical enterprise. Keeping in mind, of course, when considering the earlier Jesuit theatrical productions, that until the seventeenth century, most if not all French drama was often called comedy. And during the seventeenth century, multiple types of comedy were distinguished on the secular and college stages. The Louis le Grand performance archives mention comedy, tragi-comedy, heroic comedy, and comic drama. There was also a contemporary form called comedy-ballet, sometimes seen in court theatricals.

At Louis le Grand, comic plays were rare in the seventeenth century, but became much more frequent in the eighteenth century, beginning at least in 
1716. In some years after that, two or three comedies were performed, usually around Carnaval, and also in May or June. Some Jesuits involved in theatrical production, like Jouvency at Louis le Grand, had reservations about comedy in the college theaters. Nonetheless, from 1716 through 1758 , fifty-three dramatic comedies were performed at Louis le Grand. That period includes fifteen years without any comedy performance, though with other drama and dance performances, which means that fifty-three dramatic comedies were staged in thirtyone years. ${ }^{27}$

The Louis le Grand ballets had many comic characters. La France Victorieuse sous Louis le Grand, ${ }^{28}$ danced on August 6, 1687 , with dances probably by Beauchamps, had comic characters in at least two of its four Parts. These included Cut-purses, Chicanery, and Litigants in Part 1, and several Scaramouche dancers and "Harlequins to entertain the people" in Part 2. The Spaniards, Germans, and the Dutch in Part 3 may also have been presented as comic figures.

In Sigalion ou le secret ${ }^{29}$ performed on August 17, 1689, there were comic dancers in at least three of the Parts. The first Part had glassblowers-who, after trying to bribe the Sybils, could produce only smoked glass-and also Goblins. Part 2 included Bacchus and a band of Drunks, Indiscreet Children, Momus, and Fools. The third Part presented Old men, Orators, Litigants, and troupes of Lies.

Les Nouvelles, ${ }^{30}$ on August 6,1703 , with dances by Pécour, includes the young Apollo in Part 2, sent by his mother Latona to put water in a fountain. He is met by a hostile troupe of peasants and changes them into frogs. Their croaking tells changes in the weather. Perhaps the audience was reminded of the Latona fountain at Versailles with frog sculptures around its edges, which represented the myth of Latona's changing hostile peasants into frogs when they refused her a drink of water from their pond. The Jesuits probably made Apollo the hero of their version of the myth, because in the original version his mother Latona is very pregnant and would not have been an appropriate figure for the college stage.

L'Art de vivre heureux ${ }^{31}$ was the 1718 Louis le Grand ballet, performed on August 3, with music and songs by André Campre and M. Abeille. The third Part contains an interesting comment on Lambranzi's still recent book

\footnotetext{
27 Lowe, Marc-Antoine Charpentier, 186-94.

28 Bibliothèque nationale de France, Paris, Res. Yf 440.

29 Bibliothèque Mazarine, Paris, 1545453.

$30 \quad$ Bibliothèque nationale de France, Paris, Res. Yf 2762.

31 Bibliothèque nationale de France, Paris, Yf 2547.
} 
about the Grotesque style. In Part 3, Momus and a troupe of Grotesque dancers interrupt Terpsichore, the Greek goddess of dance, as she dances with "la plus exacte bienseance," the most precise decorum/propriety. That description indicates the "noble" dance style, as opposed to the Grotesque style. The Grotesque dancers include the Italian comedy characters Scaramouche, Polichinelle, Pierrot, Arlequin, Docteur, and others unnamed. Terpsichore chases them away.

Since comic characters were already frequent in ballets, and continued so for the next forty years, this seems unlikely to be a simple rejection of the comic dance style. I wonder if this entree in L'art de vivre heureux was a warning about including too many Grotesque dancers in a ballet, at the expense of "the most precise decorum."

L'Origine des jeux ${ }^{32}$ was performed at Louis le Grand on both August 2 and 5 . The program gave this explanation for the fourth Part's entree about the game of ninepins: A Philistine boor, living at the foot of Mt. Parnasse, overhears the Great Poets and Muses talking about poetry. Fancying himself a poet and his nine children as his Muses, he climbs the mountain to join the conversation. He is punished for his audacity by having his children changed into ninepens, and Apollo throws him off the mountain. As he rolls downhill, he becomes the ninepen ball.

It seems clear from their theatrical record that the writers and producers of the Jesuit theater considered comedy a good and allowable thing - which must not, however, be allowed to dominate either drama or ballet. Knowing more about general production of comic drama and ballet entrees in the colleges would help in better understanding their communication to their audiences and their commentary on their surrounding culture and world.

Another set of projects which would contribute to our knowledge of the Jesuit ballets and theatre in general is the translation of more Jesuit documents on the theater. For example, a readily accessible and readable English translation of Porée's 1733 Latin address on whether the theater was or might be a school of virtue would provide non-Latin and non-French speaking researchers with a reference point for eighteenth century Jesuit dramatists' attitudes toward theater production. Translations of works by the Jesuits Jouvancy and Gabriel LeJay (1657-1734) on the seventeenth- and eighteenth-century Jesuit theater would also be very helpful. And, of course, there are the mid-seventeenth century works of Menestrier on dance, especially his Des ballets anciens et modernes, which still exists only in French. Translating Des ballets would be a formidable project—one period Jesuit commented that he wished the

Le Mercure de France (August 1739): 1836-48. 
book "had not been such a cornfield of ballets." That is, the organization of the material leaves something to be desired, and especially for the modern researcher.

And finally, it would be an immeasurable service to Jesuit college ballet research, and to the fields of dance history and Jesuit history, if The Sopron Collection of Jesuit Stage Designs ${ }^{33}$ could be reprinted. The 1999 edition is nearly impossible to find now. This gorgeous and informative book is a one of a kind document for stage and costume designs from the eastern European college ballets, and invaluable for Jesuit college ballet research in general. There is nothing remotely comparable that exists from the Western European colleges.

Whatever projects future Jesuit college ballet researchers pursue, it will be important to remember that, no matter how much we think we know, we must always be alert for the startling - and perhaps unwelcome - detail, for the unexpected voice. Recently, looking through the April 1700 online issue of the Mercure monthly "newspaper," I found an account of a rhetorical display given on March 21, 1700, at the Jesuit college in Toulouse. ${ }^{34}$ A twelve-year-old student, M. de Fleyres, gave a public display of his rhetorical skills. The audience included his teachers and the worthies of the city. Both men and women were in the audience, though the women had to sit in the back rows. At the end of the student's speech, as questions began, ten-year-old Mlle de Mariotte, sitting in the back with her mother, made her way through the rows of seats to the dais and began to question M. de Fleyres. No one stopped her. The event continued and ended with M. de Fleyres and Mlle de Mariotte trading questions and answers. Any researcher of pre-suppression Jesuit schools knows that women and girls were rarely seen there, except on occasions like the summer prizegiving. And never on the rhetorical display dais. One reason no one stopped her was probably that (as the Mercure tells us) she was the daughter of a highly placed Toulouse official. The account also says that she was very well educated. Perhaps the rhetorical display had been much like other rhetorical displays and the audience was charmed and diverted by the little girl's bold action. Of course, this curious report from Toulouse simply details a surprising exception. But Mlle de Mariotte made me wonder. How often were the absolute norms and unvarying practices we deduce from our research not, in fact, so absolute or unvarying?

Exceptions do not invalidate extensive evidence of usual practice. But exceptions matter because they tell us about people and the sudden changes they

33 Eva Knapp, The Sopron Collection of Jesuit Stage Designs (Budapest: Encíklopedia Publishing, 1999).

34 Le Mercure galant (April 1700): 122-29. 
made and experienced in their daily world's surface. Those maybe-only-once changes are as real, and in more hidden ways perhaps as consequential, as the unvarying practices we deduce from our research. The most important thing I've learned doing the Jesuit college ballet research is when to hold my expert peace - that is, when to let those people who were not just us in costumes tell me what I've missed and what I need to know. 